\title{
The Use of Edible Films Based on Sodium Alginate in Meat Product Packaging: An Eco-Friendly Alternative to Conventional Plastic Materials
}

\author{
Roxana Gheorghita (Puscaselu) ${ }^{1, *}$, Gheorghe Gutt ${ }^{2}$ and Sonia Amariei ${ }^{2}$ \\ 1 Department of Health and Human Development, Stefan cel Mare University of Suceava, \\ 720229 Suceava, Romania \\ 2 Faculty of Food Engineering, Stefan cel Mare University of Suceava, 720229 Suceava, Romania; \\ g.gutt@usv.ro (G.G.); sonia@usm.ro (S.A.) \\ * Correspondence: roxana.puscaselu@usm.ro
}

Received: 16 December 2019; Accepted: 6 February 2020; Published: 12 February 2020

\begin{abstract}
The amount of plastics used globally today exceeds a million tonnes annually, with an alarming annual growth. The final result is that plastic packaging is thrown into the environment, and the problem of waste is increasing every year. A real alternative is the use bio-based polymer packaging materials. Research carried out in the laboratory context and products tested at the industrial level have confirmed the success of replacing plastic-based packaging with new, edible or completely biodegradable foils. Of the polysaccharides used to obtain edible materials, sodium alginate has the ability to form films with certain specific properties: resistance, gloss, flexibility, water solubility, low permeability to $\mathrm{O}_{2}$ and vapors, and tasteless or odorless. Initially used as coatings for perishable or cut fresh fruits and vegetables, these sodium alginate materials can be applied to a wide range of foods, especially in the meat industry. Used to cover meat products, sodium alginate films prevent mass loss and degradation of color and texture. The addition of essential oils prevents microbial contamination with Escherichia coli, Salmonella enterica, Listeria monocytogenes, or Botrytis cinerea. The obtained results promote the substitution of plastic packaging with natural materials based on biopolymers and, implicitly, of sodium alginate, with or without other natural additions. These natural materials have become the packaging of the future.
\end{abstract}

Keywords: pollution; zero-waste alternatives; sodium alginate; meat packaging

\section{Introduction to the World of Plastics: The Need for Alternative Materials}

The need to replace conventional plastic materials has become a subject of maximum interest, taking into account their intense polluting character and non-renewable nature. In modern society, these materials are found everywhere. Their excessive use is mainly due to their main characteristics: they are versatile, easy to process and manipulate, biologically inert, and can be obtained at low costs [1]. All these properties have promoted plastics intensely for various applications, from smartphones to the food industry or for 3D printing [2]. Nowadays, pollution due to plastics is found everywhere, including soil, oceans, drinking water, in human and animal bodies, and in the air. The production of plastics is expected to double over the next 20 years, surpassing to an alarming degree the current waste management and recycling capabilities [3]. It seems that plastic pollution has become the biggest environmental challenge of our time. Awareness of this problem has been achieved, with the help of non-governmental organizations and civil society, through numerous programs that publicized the current problem and helped to visualize the situation and to identify corrective measures. Even the European Union, in 2018, launched programs intended to develop strategies to reduce the use of plastics in order to protect the environment. There are two key problems that need to be solved: 
(i) the financial dimension - only $5 \%$ of the value of the plastic materials is maintained in the economy, the rest being lost after the first use, which results in annual losses of 70-105 million euros, and (ii) their reduced degradation and overly long period of time that this takes-non-recycled plastic takes years to decompose, unlike other materials such as glass, paper, or metals. Researchers studying these topics have confirmed that, to date, traces of the first plastic materials discarded in nature can still found. Thus, millions of tons of non-degradable materials reach the environment. One of the most alarming outcomes is the massive pollution of the oceans (5-13 million tons/year) [4,5]. It is also estimated that obtaining and incinerating plastics produces about 400 million tonnes of $\mathrm{CO}_{2} /$ year. The strategy being adopted by European leaders is based on the idea of bioeconomy, the ultimate goal being to protect the planet and to defend the citizens. According to these plans, by 2030, all packaging on the European Union market will be recyclable and the consumption of plastics will be reduced. The organization is committed to reducing plastic waste, stopping mass storage, and investing in stimulating and innovating new materials [6]. Rethinking and improving this system requires cooperation and efforts from all actors involved, from plastic manufacturers to recyclers, retailers, and consumers. Without the active involvement of all key players, the ultimate goal cannot be achieved-a new plastic economy. The design and production of plastic must respect the ideals of reuse and recycling, and it must have the purpose of obtaining and promoting more sustainable materials. This action will reduce pollution due to plastics and its adverse impacts on people and the environment [7].

The food industry, along with the other industries, has become a major pioneer in terms of research directions towards substituting, partially or totally, the use of conventional materials. The FAO (Food and Agricultural Organization) reports that approximately 1.3 billion tonnes of food is wasted annually globally [8]. It should be noted that these polluting sources include household, commercial, industrial, and agricultural residues. Usually, remains of the food product they contained can be found on food packaging items, along with other biological substances. In this case, their recycling is impractical and economically inconvenient, the result being that tons of plastic packaging are thrown into the environment. A significant contribution to the increase of these figures is the excessive use of disposable packaging. Obtained from non-biodegradable and non-renewable materials, these are disadvantageous from all points of view, being considered a major source of pollution. The main role of food packaging is to protect products from physical, chemical, or biological factors, thus preventing damage. The maintenance of quality and safety, as well as extending shelf life, ensures product integrity throughout the food chain, from purchase to consumption. Depending on the proximity and contact with the food, such packaging can contain three layers: the first layer is in direct contact with the food and must provide protection during storage and distribution. The second layer is not in direct contact with food and protects it from physical changes (for example, plastic boxes or flexible bags). The third layer, such as pallets or adhesive films, usually contains films incorporated into the material. This layer provides additional protection against mechanical damage and environmental or air conditions. The proposed edible packaging generally fall into the category of the first-layer films [9].

\section{Films and Coatings Used in the Food Industry}

A real and viable solution for the eradication of this worrying phenomenon-pollution due to conventional single-use materials-is the development of completely biodegradable, even edible, materials obtained from bio-based polymers. Bio-based polymers are defined as polymeric materials produced from renewable raw materials (which may or may not be biodegradable). In addition to other features, special properties such as biodegradability, regenerability, relatively low-cost development, abundance in nature, non-toxicity, and biocompatibility have made them intensively used to obtain new innovative materials [10-12]. By 2011, the production of bio-based polymers had reached the threshold of 3.2 billion tonnes, and it is expected that after 2020 it will reach the threshold of 12 billion tonnes [13]. Bio-based polymers used in the food industry can be obtained from biomass, synthesized from bio-derivative monomers, or produced from microorganisms. In the choice of such polymers, the function that the film/coating has to fulfil is taken into account. 
Moreover, the use of these films has generated increased consumer interest over minimally processed products $[14,15]$. Although it seems like a new method, it is part of a tradition; since the 16th century, lipid-based coatings have been used to cover pieces of meat [16]. The most common method of applying edible films and coatings is the use of an emulsion obtained from oil and waxes in water, which is sprayed directly on the surface of fruit in order to improve aspects of its appearance, such as gloss, color, and fineness, but also to control browning and loss of tissue water. A number of polysaccharide-based coatings, including alginates, carrageenan, cellulose derivatives, pectin, and starch derivatives have been used to improve meat quality during storage [17].

When a packing material (film, foil, thin layer, or coating) is an integral part of the food and is consumed with it, it is called an edible packaging. The coatings are applied to the surface of the food, while the films are independent structures that cover the food, being found on the surface or as a thin layer inside it. The edible nature of these materials can be achieved only when all the ingredients used are accepted by the food industry (food-grade ingredients), and the methods of obtaining the ingredients and the equipment used meet the requirements of food processing [18].

It is possible to retain product quality and freshness over the time required for commercialization and consumption if the materials and packaging technologies are correctly selected [19].

Although edible films and coatings could be classified as foods, this definition is not correct because they are not a finished product; they are not food products, they cannot be classified in a food class, and they do not have calculated nutritional value. Because they are both packaging and food components, edible films and coatings must have some characteristics, such as (a) a high sensory quality, (b) ensured mechanical efficiency and barrier property, (c) reduced permeability of water vapor, (d) biochemical, physio-chemical and microbiological stability [20], (e) non-toxic and not endangering consumers' health, (f) able to be obtained by simple technology using development processes that can be carried out at low costs [21], (g) non-polluting, (h) using cheap plant materials, (i) water resistance, (j) not producing excess $\mathrm{CO}_{2}$, (k) easily emulsified and non-sticky, (l) not interfering with the quality of the food, $(\mathrm{m})$ no taste or smell that can be detected at the time of consumption (if it has specific sensory characteristics, they must be compatible with the food), (n) reduced viscosity, (o) slightly transparent, but not like glass, and (p) capable of tolerating reduced pressures [22,23]. Although many functions of edible food packaging are similar to those of plastics (especially barrier properties against vapors and solutions), their use requires extra packaging, important for handling and hygiene reasons. The efficiency of biopolymeric films and coatings can be increased by various additions of natural substances with a role in improving the materials' physicochemical, mechanical, and microbiological characteristics [24]. This trend appeared mainly due to consumer demand for natural products. For this purpose, antioxidants, dyes, flavorings, essential oils, etc. have been added [25,26]. Research has also focused on intelligent packaging nano-materials with characteristics far superior to conventional films [19].

\section{Sodium Alginate-a Basic Component of Bio-Based Polymer Materials}

Bio-based polymer materials were invented in response to the need to replace conventional materials based on oil. They were made not to interact with the biological systems they contain. Of the majority of the hydrocolloids used, alginates have a special place, being one of the most popular and studied polysaccharides [27].

The FDA (US Food and Drug Administration) recognizes alginates as GRAS (generally recognized as safe) classified substances [28], and the EFSA (European Food Safety Authority) has authorized the use of alginate and related salts in quantum statis doses [6].

Alginates are isolated from the cell walls of brown algae (Laminaria digtata/Ascophyllum nodosum), where they are found in the form of sodium, calcium, and magnesium salts of alginic acid [29]; they can also be synthesized by microorganisms [30]. Alginate is a linear, anionic, water-soluble polysaccharide, and its most useful property— the formation of strong gels or polymers with low solubility (Figure 1) -is due to its ability to react with polyvalent metal cations, especially with calcium ions. This characteristic 
has led to the improvement of mechanical properties, barrier properties, cohesiveness, and rigidity. By increasing the concentration of cations during the gelation of alginates, a dense structure with reduced porosity is formed and a decrease in the water content or the gel permeability appears [31]. Alginate solutions can form gels by $\mathrm{pH}$ reduction.

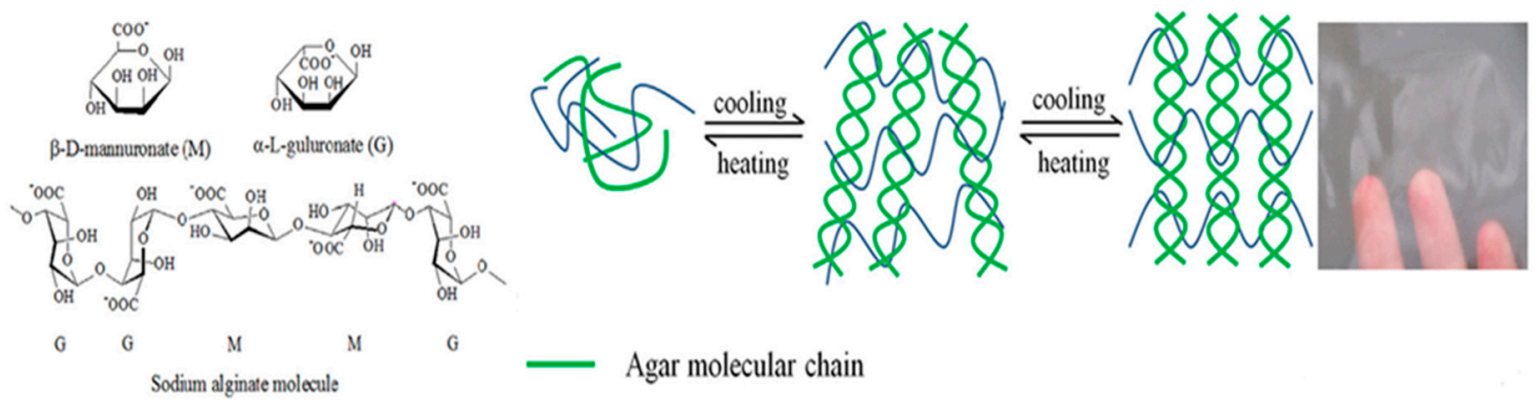

Figure 1. The sodium alginate gelling mechanism [32] (adapted from by Hou et al., Copyright 2019 Elsevier).

Due to their composition, alginates can form strong films with fibrous structure (in solid state), and are considered good filmogenic materials with characteristics comparable to those of conventional materials (Figure 2).

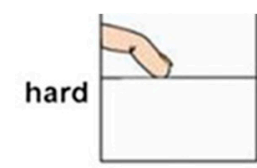

$\begin{array}{lllll}2 & 1 & 0 & 1 & 2\end{array}$

$\bigcirc \bigcirc \bigcirc \bigcirc \bigcirc$

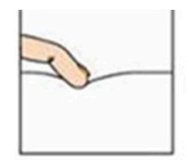

soft

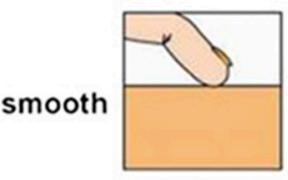

00000

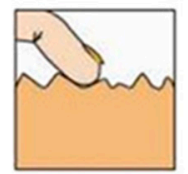

rough

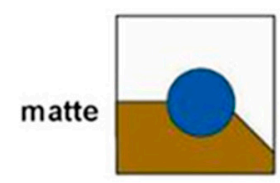

00000

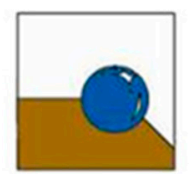

glossy

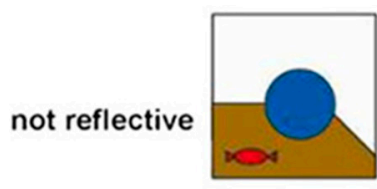

00000

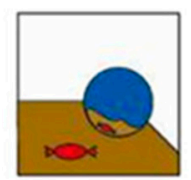

reflective

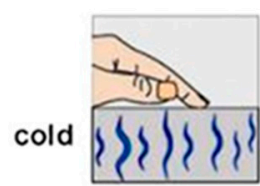

$\circ \circ 0 \circ 0$

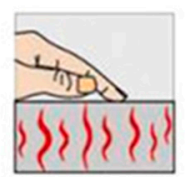

warm

not elastic

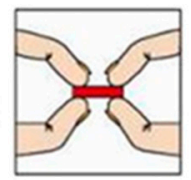

00000

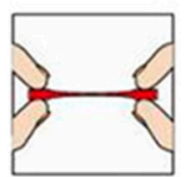

elastic

Figure 2. Cont. 


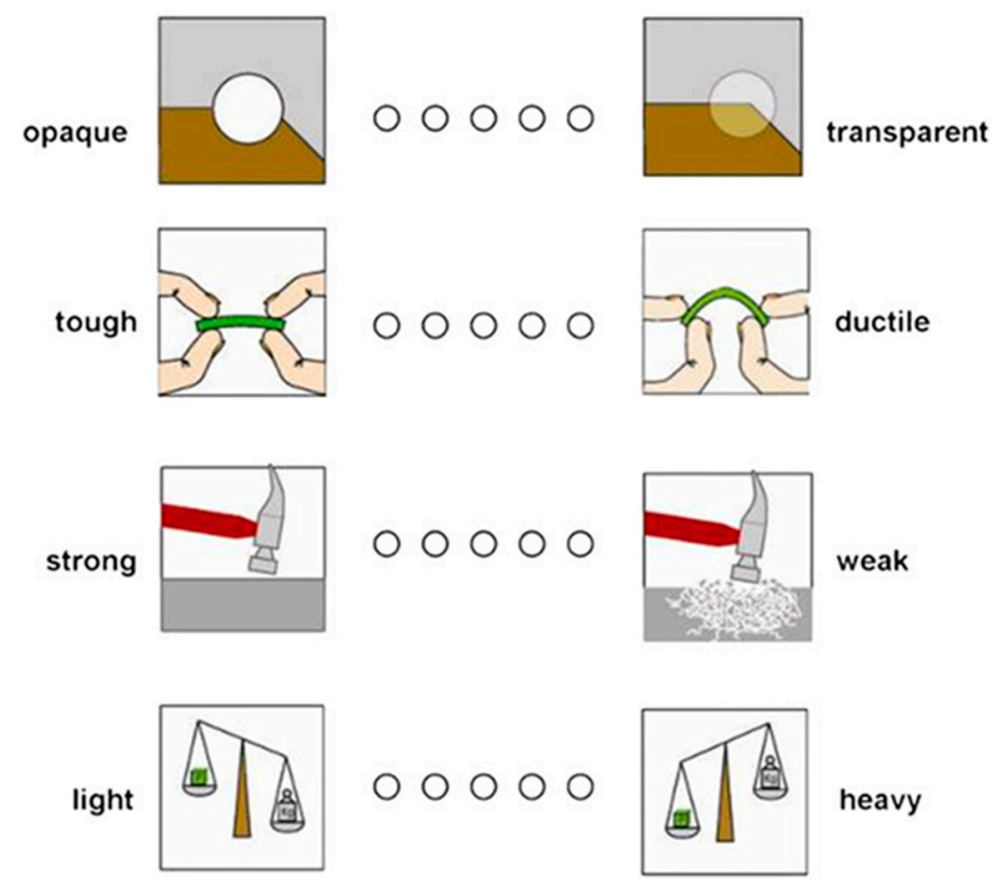

Figure 2. Material characteristics [33]. (Copyright 2012 Elsevier).

Sodium alginate is a nontoxic, biodegradable, biocompatible, and cheap hydrocolloid [34]. It may have and has many applications in the food industry as a packaging material for portioned products (Figure 3), limiting the dehydration of meat, as a thickening agent, in gel formation and as a colloidal stabilizing agent in the beverage industry, in the textile, pharmaceutical, and paper industries, and being used to obtain polymeric matrices used in the encapsulation of drugs, proteins, cells, and DNA.

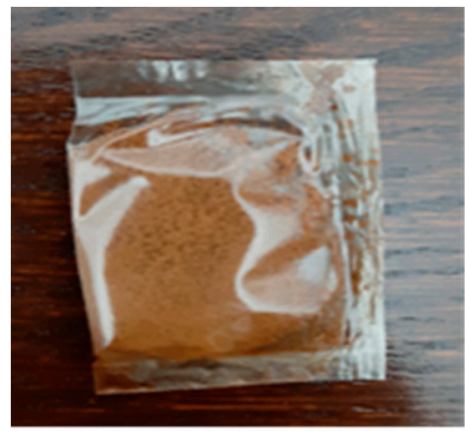

(a)

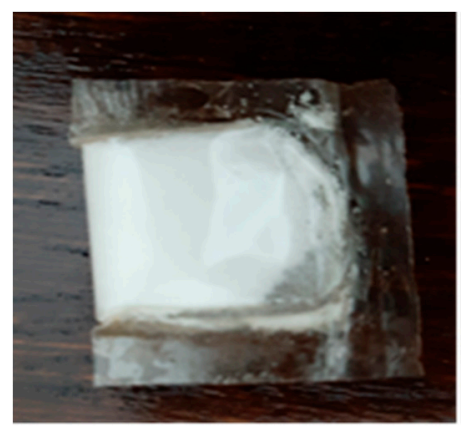

(c)

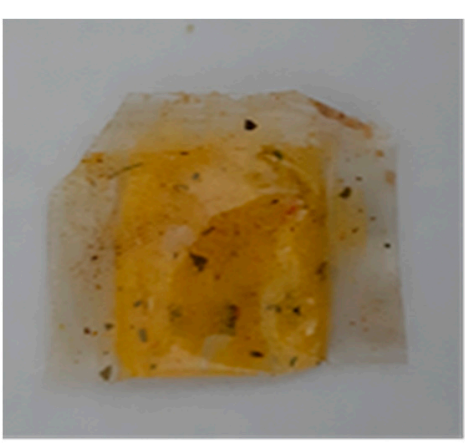

(b)

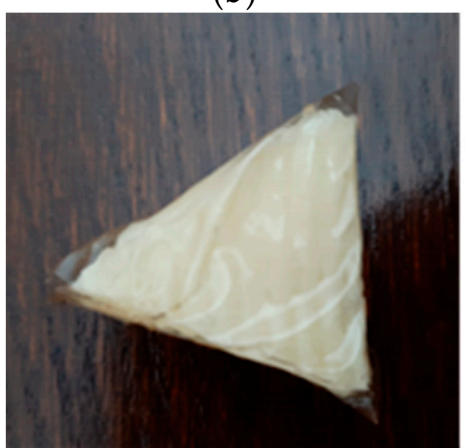

(d)

Figure 3. Cont. 


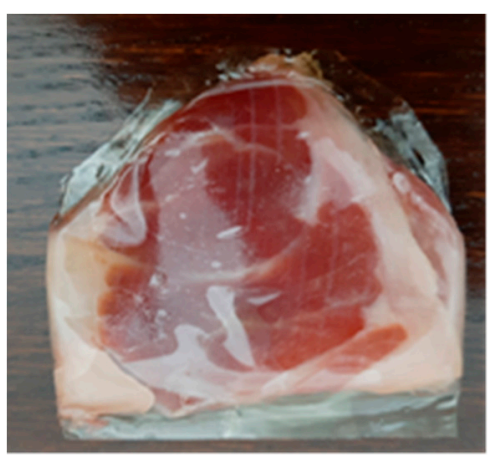

(e)

Figure 3. Applications of sodium-alginate-based edible films incorporated with Stevia rebaudiana for (a) soluble coffee, (b) dehydrated vegetables, (c) medicines in powder form, (d) cheese slices, and (e) meat slices - the pictured packaging film (both welded parts and excedentary parts) are entirely based on sodium alginate agar, and were plasticized with glycerol [35].

Sodium alginate is used in pharmaceuticals and medicine for encapsulation or as part of prolonged-release drugs [36-38], but also for gypsum, dental crowns, and prostheses, especially due to its hydrophilicity, pleasant taste, lack of odor, low cost, and ease of combination with other components and solubilization in the presence of saliva [39]. Alginate gels are currently used for cell transplants or for obtaining new tissues. They are used as substitutes for the organs or tissues of patients who have suffered certain losses $[40,41]$. They are also used in the textile industry to obtain bandages with special characteristics-bacteriostatic, antiviral, fungistatic, non-toxic, intensely absorbent, non-allergic, hemostatic, biocompatible, and allowing the respiration of the tissues and the incorporation of drugs, presenting superior mechanical properties necessary in this field [42].

Of all alginate types, sodium alginate can form films with certain specific properties: resistance, gloss, tastelessness or odorlessness, flexibility, water solubility, and low permeability to $\mathrm{O}_{2}$ or oils (Figure 2).

From a structural point of view, sodium alginate is water-soluble, linear anionic polysaccharide consisting of monomeric units of 1-4-linked $\beta$-D-mannuronate (M) and $\alpha$-L-guluronate (G). Sodium alginate has lots of hydroxyl groups, and less carboxylic acid groups. This provides the opportunity for the formation of intermolecular hydrogen bonding. Their ideal gelation mechanism is shown in Figure 2 [32].

In combination with glycerol, sodium alginate has been used to create fruit and vegetable coatings [43], thus contributing to the delay of degenerative processes and microbiological damage [44-46] by maintaining color, preserving the content of polyphenols and anthocyanins, and completely improving the quality of fruits after harvest [47-49]. Along with other hydrocolloids, it has been used to form coatings used in numerous subsectors of the food industry [31]. The easiest way to improve the characteristics of new materials is to mix in two or more biopolymers. Numerous studies have highlighted the synergistic character of sodium alginate with other biopolymers [50-53] (Table 1). 
Table 1. Synergic characteristics of composite films obtained from polysaccharides.

\begin{tabular}{|c|c|c|c|c|c|}
\hline & AGAR & STARCH & CHITOSAN & SODIUM ALGINATE & CARRAGEENAN \\
\hline AGAR & & $\begin{array}{c}+ \\
\text { low costs } \\
- \\
\text { brittle, rigid, gloss-free } \\
\text { films, with high } \\
\text { solubility, } \\
\text { low tensile strength and } \\
\text { elasticity }\end{array}$ & $\begin{array}{c}+ \\
\text { decreases color intensity, } \\
\text { increases transparency and gloss; } \\
\text { antibacterial properties }\end{array}$ & low tensile strength & $\begin{array}{l}- \\
\text { increases hydration capacity } \\
\text { and vapor permeability }\end{array}$ \\
\hline STARCH & $\begin{array}{c}+ \\
\text { homogeneous microstructure, } \\
\text { good barrier and mechanical } \\
\text { properties }\end{array}$ & & $\begin{array}{c}+ \\
\text { increases mechanical strength, } \\
\text { decreases vapor permeability and } \\
\text { solubility; } \\
\text { antibacterial effect }\end{array}$ & $\stackrel{+}{\text { high water-holding capacity }}$ & $\begin{array}{c}+ \\
\text { improved mechanical } \\
\text { properties } \\
- \\
\text { increases oxygen } \\
\text { permeability }\end{array}$ \\
\hline CHITOSAN & $\begin{array}{c}+ \\
\underset{\text { improved mechanical }}{\text { properties }}\end{array}$ & $\begin{array}{c}- \\
\text { reduced mechanical } \\
\text { properties; low gloss and } \\
\text { transparency }\end{array}$ & & $\begin{array}{c}+ \\
\text { allows compound } \\
\text { encapsulation } \\
- \\
\text { low mechanical performance }\end{array}$ & $\begin{array}{l}+ \\
\text { allows the encapsulation of } \\
\text { controlled-release } \\
\text { compounds } \\
- \\
\text { increases hydration capacity } \\
\text { and solubility }\end{array}$ \\
\hline SODIUM ALGINATE & $\begin{array}{c}+ \\
\begin{array}{c}\text { homogeneous, flexible, and } \\
\text { fine films }\end{array}\end{array}$ & $\begin{array}{l}\text { high solubility, more } \\
\text { brittle films }\end{array}$ & $\begin{array}{c}+ \\
\text { allows encapsulation of } \\
\text { compounds }\end{array}$ & & $\begin{array}{c}+ \\
\text { vapor permeability decreases } \\
- \\
\text { low mechanical properties }\end{array}$ \\
\hline CARRAGE-ENAN & $\begin{array}{c}+ \\
\text { reduces hydration capacity; } \\
\text { more flexible and elastic films } \\
- \\
\text { reduces transparency }\end{array}$ & $\begin{array}{c}+ \\
\text { low cost } \\
- \\
\text { low flexibility and } \\
\text { elasticity, high solubility }\end{array}$ & $\stackrel{+}{\text { encapsulation of compounds }}$ & low elongation at break & \\
\hline
\end{tabular}




\section{Sodium Alginate-a Basic Component of Packaging Materials in the Meat Industry}

The meat industry has always been one of the most polluting food industries. One intense environmental polluting factor is the packaging materials used. Plastics are especially preferred by manufacturers because of their properties. When a single applied layer cannot meet all the required characteristics, several laminate films are usually used. Besides the polluting nature of the materials when used independently, these complex films are extremely harmful due to the use of different compositions and the adhesives used for the overlap; all these practices make them impossible to sort and recycle once they become waste.

Edible films and coatings may be applied to meat and poultry products by foaming, dipping, spraying, casting, brushing, individual wrapping, rolling, or vacuum impregnation (Figure 4).

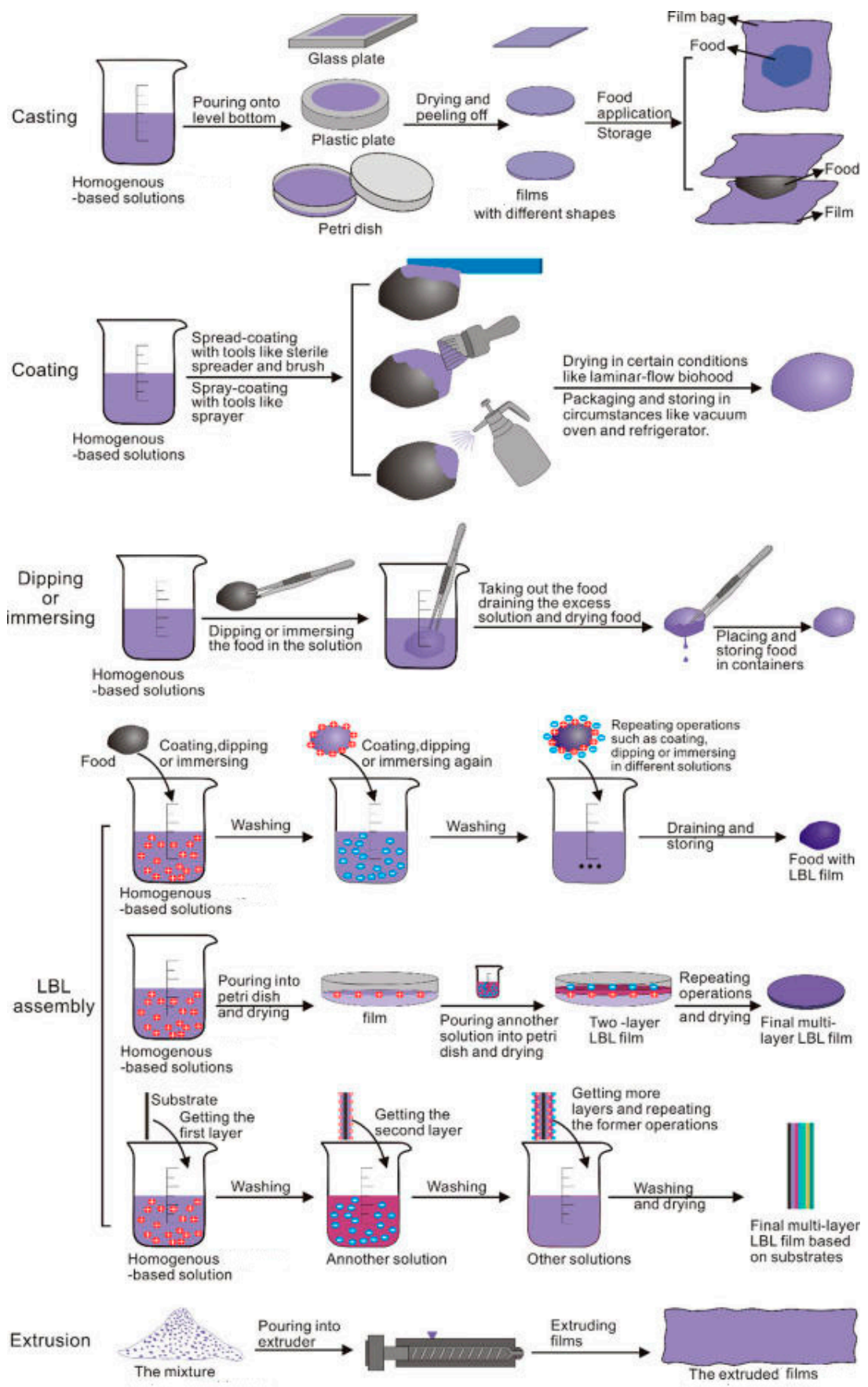

Figure 4. Ways of obtaining and applying films and coatings (adaptation by Wang, et al., 2018, [54]). 
Foam application is used for those film-forming solutions that come in the form of an emulsion and requires the existence of a foaming agent; the coating is obtained with the help of compressed air; brushing is used for full application of the coating on the product surface; and a spray is generally used when the films are thin or when the coating is applied only on one side of the product [55]. The vacuum-impregnation method is used to enrich a product with vitamins or minerals [56]. Films are applied by the method of casting or extrusion when looking at composite or multilayer films [57]. In the meat industry, the packaging is first and foremost intended to protect the product from permeability to vapors and gases [58]. This should prevent mass loss and degradation of meat color [59]. Studies have shown the possibility of replacing these conventional materials with edible films based on biopolymers, especially polysaccharides, because they can extend the term of validity of meat and meat products by preventing dehydration, rancidity or browning of the muscle tissue [60]. Applied to meat products subjected to smoking or steaming, edible films dissolve on the surface of products, improving the structure and texture, and preventing moisture transfer [61]. In addition to its non-polluting, biodegradable, renewable nature, edible packaging may include various natural substances that play a role in maintaining and improving the quality of the packaged products, such as organic acids, essential oils, or plant extracts (Table 2), bacteriocins, antioxidants, colorings, flavorings, vitamins etc. The addition of antimicrobial substances to a food formula or in the materials used for food packaging is regulated by the FDA, which specifies the exact quantity permitted [62].

Table 2. Films based on sodium alginate with essential oil additives used in the food industry.

\begin{tabular}{|c|c|c|c|}
\hline Food & Essential Oils Added & Results & References \\
\hline Cheese & Pimpinella saxifrage & $\begin{array}{l}\text { The addition of PSEO }(1 \%-3 \%) \text { in sodium alginate coating } \\
\text { ( } 2 \% \text { sodium alginate }+15 \% \text { glycerol) was effective in reducing the } \\
\text { weight loss, preserving pH and color and improving the oxidative } \\
\text { and bacterial stability of the coated cheese. }\end{array}$ & [63] \\
\hline $\begin{array}{l}\text { Apples and } \\
\text { pears }\end{array}$ & Cinnamon & $\begin{array}{l}\text { Inhibition of growth and toxin production of Aspergillus } \\
\text { carbonarius growth and ochratoxin A production. }\end{array}$ & [64] \\
\hline $\begin{array}{l}\text { Bighead carp } \\
\text { fillets }\end{array}$ & $\begin{array}{l}\text { Horsemint } \\
\text { (Mentha longifolia) }\end{array}$ & $\begin{array}{l}\text { Samples treated showed significantly lower lipid oxidation } \\
\text { during the storage period and reduced degree of microbial } \\
\text { deterioration. Antioxidant and antibacterial effects of sodium } \\
\text { alginate coating and horsemint were more pronounced when a } \\
\text { horsemint was used at } 1 \% \text { concentration. }\end{array}$ & [28] \\
\hline $\begin{array}{l}\text { Fresh-cut } \\
\text { papaya }\end{array}$ & $\begin{array}{l}\text { Thyme (Thymus } \\
\text { vulgaris) and oregano } \\
\text { (Origanum vulgare) }\end{array}$ & $\begin{array}{l}\text { Retarded the degradation rate of physicochemical properties, } \\
\text { improved microbiological food safety and had the highest sensory } \\
\text { evaluation scores for fresh-cut papaya stored for } 12 \text { days at } 4{ }^{\circ} \mathrm{C} \text {. }\end{array}$ & [27] \\
\hline Fresh-cut apple & Lemongrass & Inactivation of Escherichia coli. & [45] \\
\hline Strawberry & Carvacrol & $\begin{array}{l}\text { Carvacrol was effective against both Escherichia coli and } \\
\text { Botrytis cinerea. }\end{array}$ & [65] \\
\hline $\begin{array}{l}\text { Fresh-cut } \\
\text { apples }\end{array}$ & $\begin{array}{l}\text { Cinnamon, clove, and } \\
\text { lemongrass }\end{array}$ & $\begin{array}{c}\text { The coatings applied on apple pieces maintained the } \\
\text { physicochemical characteristics of the apple pieces for more than } \\
30 \text { days, decreased the respiration rate, reduced the Escherichia coli } \\
\text { population by about } 1.23 \log \text { CFU/g at day } 0 \text {, and extended the } \\
\text { microbiological shelf life by at least } 30 \text { days. }\end{array}$ & [66] \\
\hline Strawberry & Citral and eugenol & $\begin{array}{l}\text { Alginate edible with essential oils added improved the coatings in } \\
\text { most cases, better preserved sensory and nutritional attributes, } \\
\text { and reduced microbial spoilage. }\end{array}$ & [67] \\
\hline $\begin{array}{l}\text { Fresh-cut } \\
\text { cantaloupes }\end{array}$ & $\begin{array}{l}\text { Cinnamon bark oil and } \\
\text { soybean oil }\end{array}$ & $\begin{array}{c}\text { Cocktails of Salmonella enterica, Escherichia coli O157:H7, or Listeria } \\
\text { monocytogenes inoculated onto cantaloupes were reduced to the } \\
\text { detection limit and completely inhibited during } 15 \text { day storage } \\
\text { with the coating treatment. }\end{array}$ & {$[68]$} \\
\hline $\begin{array}{l}\text { Fresh-cut } \\
\text { pineapple }\end{array}$ & Lemongrass & $\begin{array}{c}\text { The results indicate that an alginate-based edible coating } \\
\text { formulation incorporated with } 0.3 \%(w / v) \text { lemongrass has } \\
\text { potential to extend the shelf life and maintain quality of } \\
\text { fresh-cut pineapple. }\end{array}$ & [69] \\
\hline $\begin{array}{l}\text { Fresh-cut } \\
\text { melon }\end{array}$ & $\begin{array}{l}\text { Cinnamon, palmarosa, } \\
\text { and lemongrass }\end{array}$ & $\begin{array}{l}\text { Palmarosa oil incorporated at } 0.3 \% \text { into the coating was shown to } \\
\text { be a promising preservation alternative for fresh-cut melon, since } \\
\text { it had a good acceptation by panelists, maintained the fruit } \\
\text { quality parameters, inhibited the native flora growth, and reduced } \\
\text { Salmonella enteritidis population. }\end{array}$ & [70] \\
\hline
\end{tabular}


Antimicrobial packaging is a necessary and very important tool in protecting meat from contamination with pathogenic microorganisms. Contamination of meat products usually starts from the outer surface due to the microbial load resulting from improper processing and handling of the raw material and packaging. Antimicrobial films can prevent the contamination of meat and meat products during cold storage, but can also be used to inhibit microorganisms on the surface of freshly processed products, thus avoiding cross-contamination and increasing shelf life (Table 3). The prolonged, gradual release of antimicrobial substances from the structure of edible foils used for packing meat and meat products is a much more beneficial solution than their incorporation into the product [71,72].

The materials used for packing meat and meat products can be smart packaging, a principle based on two concepts: active and intelligent packaging. Active packaging refers to the existence of additives on the surface of a packaging material, attached inside it or incorporated into its structure, which play a role in maintaining the quality and extending the validity term of a product. Smart packaging systems, however, are designed to monitor certain characteristics of either packaged products or the environment in which they are found [73], and to provide information on product quality and consumption safety [74]. They can be sensors (electronic noses, biosensors, or chemical sensors) or indicators (freshness, time-temperature, integrity) [13,75].

Table 3. Alginate-based films and coatings with applicability in the meat industry.

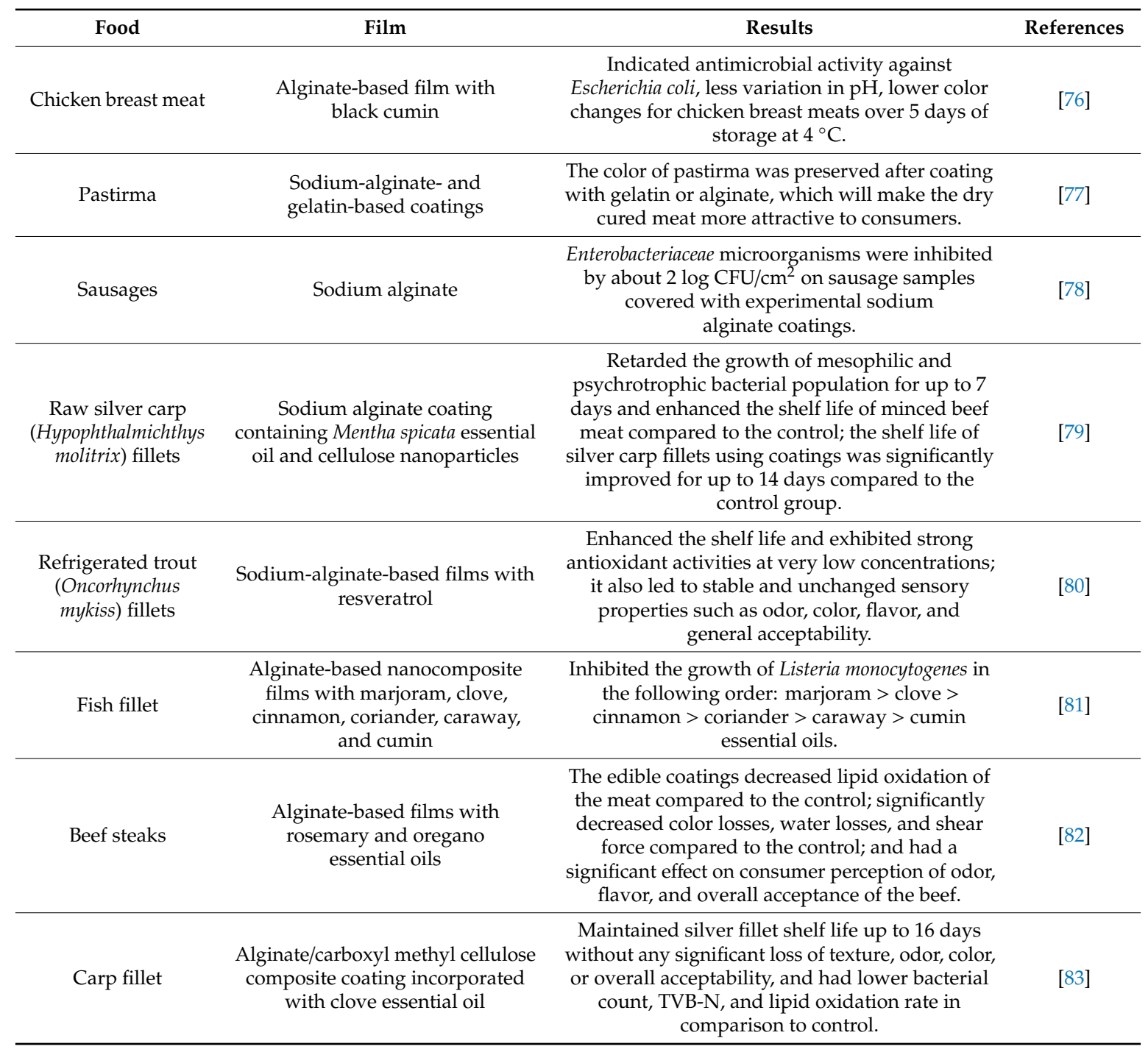


Table 3. Cont.

\begin{tabular}{|c|c|c|c|}
\hline Food & Film & Results & References \\
\hline Chicken meat & $\begin{array}{l}\text { Sodium alginate coating } \\
\text { incorporated with nisin, } \\
\text { Cinnamomum zeylanicum, and } \\
\text { rosemary essential oils }\end{array}$ & $\begin{array}{c}\text { Longer storage of chicken breast at refrigerated } \\
\text { temperatures }\left(4^{\circ} \mathrm{C}\right) \text {; reduced the degradation of } \\
\text { bioactive compounds and maintained the } \\
\text { nutritional quality. }\end{array}$ & [84] \\
\hline $\begin{array}{l}\text { Baked ham and } \\
\text { bologna sliced }\end{array}$ & $\begin{array}{l}\text { Alginate films and essential oils of } \\
\text { oregano, cinnamon, savory }\end{array}$ & $\begin{array}{c}\text { Reductions populations of Salmonella enterica and } \\
\text { Listeria monocytogenes in bologna and baked ham } \\
\text { slices when applying alginate films with } \\
\text { cinnamon essential oil. }\end{array}$ & [85] \\
\hline Fish fillet & $\begin{array}{l}\text { Gelatin-alginate film containing } \\
\text { oregano essential oil }\end{array}$ & $\begin{array}{l}\text { Study showed that film was an effective } \\
\text { antimicrobial suitable for potential food } \\
\text { packaging applications; use of the OEO blend } \\
\text { film delayed bacterial growth over } 15 \text { days } \\
\text { of storage. }\end{array}$ & [86] \\
\hline Beef muscle & $\begin{array}{l}\text { Sodium alginate and oregano, } \\
\text { cinnamon, savory oils }\end{array}$ & $\begin{array}{c}\text { After } 5 \text { days of storage, films containing oregano } \\
\text { or cinnamon essential oils were the most effective } \\
\text { against Salmonella typhimurium. }\end{array}$ & [87] \\
\hline Fish fillets & $\begin{array}{l}\text { Alginate-calcium coating with } \\
\text { cinnamon and nisin }\end{array}$ & $\begin{array}{l}\text { Cinnamon in alginate-calcium coating } \\
\text { treatments could efficiently maintain quality } \\
\text { during storage, but colors of fish fillets were } \\
\text { evidently changed due to the color of cinnamon. }\end{array}$ & [88] \\
\hline $\begin{array}{l}\text { Rainbow trout } \\
\text { fillets }\end{array}$ & $\begin{array}{l}\text { Alginate coating containing } \\
\text { lactoperoxidase system and } \\
\text { Zataria multiflora Boiss essential oil }\end{array}$ & $\begin{array}{l}\text { Alginate coating, when used with no } \\
\text { antimicrobial agent, had a supportive effect on } \\
\text { the growth of Listeria monocytogenes and } \\
\text { Escherichia coli O157:H7 pathogenic bacteria. }\end{array}$ & [89] \\
\hline
\end{tabular}

The packaging of a food product influences the consumer in their choice and willingness to pay for it.

Thus, there are two avenues by which to tempt a consumer: either by using attractive images on the front of the packaging, or by the existence of transparent areas in the packaging material so that the consumer can observe the food. The use of hydrocolloid films based on sodium alginate can facilitate this aspect, as the product can be evaluated over its whole surface. Research has shown that, lately, producers have been choosing the second option, because it seems that the product packed in such materials is not only preferred by consumers over others, but also encourages them to buy food in higher quantities [90]. These materials are easy to apply to ready-to-eat foods, which are extremely modern today. They can also be successfully used for wrapping packages containing a single portion, made precisely to avoid wasting food [91]. Only the use of edible or biodegradable materials can reduce the amount of conventional disposable plastic packaging used for this purpose.

\section{Conclusions and Future Perspectives}

In conclusion, one thing has become clear: regular plastic packaging materials used in the food industry, often for single uses, are polluting. Viable solutions to this problem include the use of alternative packaging materials-natural, obtained from bio-based polymers, biodegradable, and even edible. Studies and research in this regard highlight the use of films and coatings successfully applied to products across the entire food chain.

Sodium alginate has proven effective in the food industry, but also in other important human industries, such as medicine and pharmaceutics. Used as a packing material in the meat industry, it protects the product from the evaporation of water content, color loss, and gas transfer and prevents microbial contamination. For the continuous improvement of these characteristics, further research is required to identify new types of films and foils with improved features, which could maintain and even increase the quality of products throughout the food chain, aimed, in particular, at increasing shelf life. Similarly, it is possible to identify natural substances with nutritional, pre-/probiotic, antioxidant, or anti-browning agents that can ensure the quality of packaged products for a longer period. 
Developing awareness campaigns for producers and consumers can have a positive effect in amplifying the use of new packaging materials.

This is the packaging of the future.

Author Contributions: Concept, method, investigation and draft writing-R.G.; Analysis-G.G. and S.A.; Writing editing-S.A.; Supervision-G.G. and S.A.; Project management-G.G. All authors have read and agreed to the published version of the manuscript.

Funding: This work was supported by contract no. 18PFE/16.10.2018 funded by Ministry of Research and Innovation within Program 1-Development of national research and development system, Subprogram 1.2-Institutional Performance -RDI excellence funding projects.

Acknowledgments: The authors are thankful to the "B\&V The Agar Company", Italia, for their support to the development of this study and for providing the materials necessary for successfully conclude this research.

Conflicts of Interest: The authors declare no conflict of interest.

\section{References}

1. Ananda, A.P.; Manukumar, H.M.; Umesha, S.; Soumya, G.; Priyanka, D.; Kumar, A.S.M.; Krishnamurthy, N.B.; Savitha, K.R. A Relook at Food Packaging for Cost Effective by Incorporation of Novel Technologies. J. Packag. Technol. Res. 2017, 1, 67-85. [CrossRef]

2. Andrady, A.L. Plastics and Environmental Sustainability: Fact and Fiction; John Wiley \& Sons: Hoboken, NJ, USA, 2015.

3. Ellen MacArthur Foundation. The New Plastics Economy: Catalysing Action; Ellen MacArthur Foundation and World Economic Forum: Davos, Switzerland, 2017.

4. Available online: https://ec.europa.eu/commission/news/first-ever-europe-wide-strategy-plastics-2018-jan16_ro (accessed on 1 December 2019).

5. Haward, M. Plastic pollution of the world's seas and oceans as a contemporary challenge in ocean governance. Nat. Commun. 2018, 9, 667. [CrossRef] [PubMed]

6. Available online: https://ec.europa.eu/commission/presscorner/detail/en/IP_18_5 (accessed on 1 December 2019).

7. Available online: https://efsa.onlinelibrary.wiley.com/doi/epdf/10.2903/j.efsa.2017.5049 (accessed on 9 December 2019).

8. Available online: https://eur-lex.europa.eu/legal-content/EN/TXT/?qid=1516265440535\&uri=COM:2018:28: FIN (accessed on 1 December 2019).

9. Tsang, Y.F.; Kumar, V.; Samadar, P.; Yang, Y.; Lee, J.; Ok, Y.S.; Song, H.; Kim, K.-H.; Kwon, E.E.; Jeon, Y.J. Production of bioplastic through food waste valorization. Environ. Int. 2019, 127, 625-644. [CrossRef] [PubMed]

10. Hammam, A.R.A. Technological, applications, and characteristics of edible films and coatings: A review. SN Appl. Sci. 2019, 1, 632. [CrossRef]

11. Vargas, M.; Pastor, C.; Chiralt, A.; McClements, D.J.; González-Martínez, C. Recent Advances in Edible Coatings for Fresh and Minimally Processed Fruits. Crit. Rev. Food Sci. Nutr. 2008, 48, 496-511. [CrossRef]

12. Biji, K.B.; Ravishankar, C.N.; Mohan, C.O.; Gopal, T.K.S. Smart packaging systems for food applications: A review. J. Food Sci. Technol. 2015, 52, 6125-6135. [CrossRef]

13. Calva-Estrada, S.J.; Jiménez-Fernández, M.; Lugo-Cervantes, E. Protein-Based Films: Advances in the Development of Biomaterials Applicable to Food Packaging. Food Eng. Rev. 2019, 11, 78-92. [CrossRef]

14. Crouvisier-Urion, K.; Lagorce-Tachon, A.; Lauquin, C.; Winckler, P.; Tongdeesoontorn, W.; Domenek, S.; Debeaufort, F.; Karbowiak, T. Impact of the homogenization process on the structure and antioxidant properties of chitosan-lignin composite films. Food Chem. 2017, 236, 120-126. [CrossRef]

15. Majid, I.; Nayik, G.A.; Dar, S.M.; Nanda, V. Novel food packaging technologies: Innovations and future prospective. J. Saudi Soc. Agric. Sci. 2016, 17, 454-462. [CrossRef]

16. Parreidt, T.S.; Müller, K.; Schmid, M. Alginate-Based Edible Films and Coatings for Food Packaging Applications. Foods 2018, 7, 170. [CrossRef]

17. Kester, J.; Fennema, O. Edible films and coatings: A review. Food Technol. 1986, $48,47$.

18. Contreras-Medellin, R.; Labuza, T.P. Prediction of moisture protection requirements for foods. Cereal Food World 1981, 26, 335. 
19. Valdés, A.; Ramos, M.; Beltrán, A.; Jiménez, A.; Garrigós, M.C. State of the Art of Antimicrobial Edible Coatings for Food Packaging Applications. Coatings 2017, 7, 56. [CrossRef]

20. Kuswandi, B. Environmental friendly food nano-packaging. Environ. Chem. Lett. 2017, 15, $205-221$. [CrossRef]

21. Costa, M.J.; Maciel, L.C.; Teixeira, J.A.; Vicente, A.A.; Cerqueira, M.A. Use of edible films and coatings in cheese preservation: Opportunities and challenges. Food Res. Int. 2018, 107, 84-92. [CrossRef]

22. Hassan, B.; Chatha, S.A.S.; Hussain, A.I.; Zia, K.M.; Akhtar, N. Recent advances on polysaccharides, lipids and protein based edible films and coatings: A review. Int. J. Boil. Macromol. 2018, 109, 1095-1107. [CrossRef]

23. Dehghani, S.; Hosseini, S.V.; Regenstein, J.M. Edible films and coatings in seafood preservation: A review. Food Chem. 2017, 240, 505-513. [CrossRef]

24. Galgano, F. Biodegradable packaging and edible coating for fresh-cut fruits and vegetables. Ital. J. Food Sci. 2015, 27. [CrossRef]

25. Rai, M.; Ingle, A.P.; Gupta, I.; Pandit, R.; Paralikar, P.; Gade, A.; Chaud, M.V.; Dos Santos, C.A. Smart nanopackaging for the enhancement of food shelf life. Environ. Chem. Lett. 2018, 17, 277-290. [CrossRef]

26. Ramos, M.; Valdés, A.; Beltrán, A.; Garrigós, M.C. Gelatin-Based Films and Coatings for Food Packaging Applications. Coatings 2016, 6, 41. [CrossRef]

27. Tabassum, N.; Khan, M.A. Modified atmosphere packaging of fresh-cut papaya using alginate based edible coating: Quality evaluation and shelf life study. Sci. Hortic. 2020, 259, 108853. [CrossRef]

28. Heydari, R.; Bavandi, S.; Javadian, S.R. Effect of sodium alginate coating enriched with horsemint (Mentha longifolia) essential oil on the quality of bighead carp fillets during storage at $4{ }^{\circ} \mathrm{C}$. Food Sci. Nutr. 2015, 3, 188-194. [CrossRef] [PubMed]

29. Younes, M.; Aggett, P.; Aguilar, F.; Crebelli, R.; Filipič, M.; Jose Frutos, M.; Galtier, P.; Gott, D.; Gundert-Remy, U.; Georg Kuhnle, G. Re-evaluation of Alginic Acid and its Sodium, Potassium, Ammonium and Calcium Salts (e 400-e 404) as Food Additives. EFSA J. 2017, 15, e05049.

30. Fat Moradali, M.; Ghods, S.; Rehm, B. Alginate Biosynthesis and biotechnological production. Chem. Mater. Sci. 2017, 11. [CrossRef]

31. Alboofetileh, M.; Rezaei, M.; Hosseini, H.; Abdollahi, M. Antimicrobial activity of alginate/clay nanocomposite films enriched with essential oils against three common foodborne pathogens. Food Control. 2014, 36, 1-7. [CrossRef]

32. Hou, X.; Xue, Z.; Xia, Y.; Qin, Y.; Zhang, G.; Liu, H.; Li, K. Effect of $\mathrm{SiO}_{2}$ nanoparticle on the physical and chemical properties of eco-friendly agar/sodium alginate nanocomposite film. Int. J. Boil. Macromol. 2019, 125, 1289-1298. [CrossRef]

33. Karana, E. Characterisation of 'natural' and 'high-quality' materials to improve perception of bio-plastics. J. Clean. Prod. 2012, 37, 316-325. [CrossRef]

34. Majdinasab, M.; Hosseini, S.M.H.; Sepidname, M.; Negahdarifar, M.; Li, P. Development of a novel colorimetric sensor based on alginate beads for monitoring rainbow trout spoilage. J. Food Sci. Technol. 2018, 55, 1695-1704. [CrossRef]

35. Puscaselu, R.; Gutt, G.; Amariei, S. Gheorghe Biopolymer-Based Films Enriched with Stevia rebaudiana Used for the Development of Edible and Soluble Packaging. Coatings 2019, 9, 360. [CrossRef]

36. Rowson, J.; Sangrar, A.; Rodriguez-Falcon, E.; Bell, A.; Walton, K.; Yoxall, A.; Kamat, S. Rating accesability of packaging: A medical packaging example. Packag. Technol. Sci. 2016, 29, 607. [CrossRef]

37. Septianto, F.; Lee, M.S. Emotional responses to plastic waste: Matching image and message framing in encouraging consumers to reduce plastic consumption. Australas. Mark. J. (AMJ) 2019. [CrossRef]

38. Wróblewska-Krepsztul, J.; Rydzkowski, T.; Michalska-Pożoga, I.; Thakur, V.K. Biopolymers for Biomedical and Pharmaceutical Applications: Recent Advances and Overview of Alginate Electrospinning. Nanomaterials 2019, 9, 404. [CrossRef] [PubMed]

39. Mdhavan, S. A review on Hydrocolloids-Agar and Alginate. Int. J. Pharm. Sci. Res. 2015, 7, 704-707.

40. Langer, R.; Vacanti, J.P. Tissue engineering. Science 1993, 260, 920-926. [CrossRef] [PubMed]

41. Deepthi, S.; Jayakumar, R. Alginate nanobeads interspersed fibrin network as in situ forming hydrogel for soft tissue engineering. Bioact. Mater. 2017, 3, 194-200. [CrossRef] [PubMed]

42. Rinaudo, M. Biomaterials based on a natural polysaccharide: Alginate. TIP 2014, 17, 92-96. [CrossRef]

43. Galus, S. Development of edible coatings in the preservation of fruits and vegetables. In Polymers for Agri-Food Applications; Springer: Berlin, Germany, 2019; pp. 377-390. 
44. Salvia-Trujillo, L.; Rojas-Graü, M.A.; Soliva-Fortuny, R.; Martín-Belloso, O. Use of antimicrobial nanoemulsions as edible coatings: Impact on safety and quality attributes of fresh-cut Fuji apples. Postharvest Boil. Technol. 2015, 105, 8-16. [CrossRef]

45. Appendini, P.; Hotchkiss, J.H. Review of antimicrobial food packaging. Innov. Food Sci. Emerg. Technol. 2002, 3, 113-126. [CrossRef]

46. Cagri, A.; Ustunol, Z.; Ryser, E.T. Antimicrobial Edible Films and Coatings. J. Food Prot. 2004, 67, $833-848$. [CrossRef]

47. Chiabrando, V.; Giacalone, G. Effects of alginate edible coating on quality and antioxidant properties in sweet cherry during postharvest storage. Ital. J. Food Sci. 2015, 27, 173-180.

48. Tavassoli-Kafrani, E.; Shekarchizadeh, H.; Masoudpour-Behabadi, M. Development of edible films and coatings from alginates and carrrageenans. Carbohydr. Polym. 2016, 37, 360-374. [CrossRef] [PubMed]

49. Maftoonazad, N.; Ramaswamy, H.S.; Marcotte, M. Shelf-life extension of peaches through sodium alginate and methyl cellulose edible coatings. Int. J. Food Sci. Technol. 2008, 43, 951-957. [CrossRef]

50. Wang, L.F.; Rhim, J.W. Preparation and application og agar/alginate/collagen ternary blend functional food packaging films. Int. J. Biol. Macromol. 2015, 80, 460-468. [CrossRef] [PubMed]

51. Kotikalapudi, B.; Low, N.; Nickerson, M.; Korber, D. In vitro characterization of probiotic survival, adherence and antimicrobial resistance: Candidate selection for encapsulation in a pea protein isolate-alginate delivery system. Int. J. Probiotics Prebiotics 2010, 5, 1-12.

52. Paula, G.; Benevides, N.; Cunha, A.; de Oliveira, A.V.; Pinto, A.; Morais, J.; Azeredo, H. Development and characterization of edible films from mixtures of k-carrageenan, i-carrageenan, and alginate. Food Hydrocoll. 2015, 47, 140-145. [CrossRef]

53. Repossi, A.; Farabegoli, F.; Gazzotti, T.; Zironi, E.; Pagliuca, G. Bisphenol A in Edible Part of Seafood. Ital. J. Food Saf. 2016, 5, 98-105. [CrossRef]

54. Wang, H.; Qian, J.; Ding, F. Emerging Chitosan-Based Films for Food Packaging Applications. J. Agric. Food Chem. 2018, 66, 395-413. [CrossRef]

55. Huber, K.; Embuscado, E. Edible Films and Coatings for Food Applications; Springer: New York, NY, USA, 2009; pp. 245-268. ISBN 978-0-387-92823-4.

56. Parreidt, T.S.; Schmid, M.; Müller, K. Effect of Dipping and Vacuum Impregnation Coating Techniques with Alginate Based Coating on Physical Quality Parameters of Cantaloupe Melon. J. Food Sci. 2018, 83, 929-936. [CrossRef]

57. Skurtys, O.; Acevedo, C.; Pedreschi, F.; Enrione, J.; Osorio, F.; Aguilera, J.M. Food hydrocolloid edible films and coatings. In Food Hydrocolloids Characteristics, Properties and Structures; Hollingworth, C.S., Ed.; Nova Science Publishers, Inc.: New York, NY, USA, 2010; pp. 41-80.

58. Troy, D.; Kerry, J. Consumer perception and the role of science in the meat industry. Meat Sci. 2010, 86, 214-226. [CrossRef]

59. Haile, D.; De Smet, S.; Claeys, E.; Vossen, E. Effect of light, packaging condition and dark storage durations on colour and lipid oxidative stability of cooked ham. J. Food Sci. Technol. 2013, 50, 239-247. [CrossRef]

60. Sánchez-Ortega, I.; García-Almendárez, B.E.; Santos-López, E.M.; Amaro-Reyes, A.; Barboza-Corona, J.E.; Regalado, C. Antimicrobial Edible Films and Coatings for Meat and Meat Products Preservation. Sci. World J. 2014, 2014, 1-18. [CrossRef] [PubMed]

61. Cutter, C.N. Opportunities for bio-based packaging technologies to improve the quality and safety of fresh and further processed muscle foods. Meat Sci. 2006, 74, 131-142. [CrossRef] [PubMed]

62. Malhotra, B.; Keshwani, A.; Kharkwal, H. Antimicrobial food packaging: Potential and pitfalls. Front. Microbiol. 2015, 6, 1-9. [CrossRef] [PubMed]

63. Ksoudaa, G.; Sellimia, S.; Merlierb, F.; Falcimaigne, A.; Thomassetb, B.; Nasria, M.; Hajjia, M. Composition, antibacterial and antioxidant activities of Pimpinella saxifrage essential oil and application to cheese preservation as coating additive. Food Chem. 2019, 288, 47-56. [CrossRef]

64. Kapetanakoua, A.; Nestoraa, S.; Evagelioub, V.; Skandamisa, P. Sodium alginate-cinnamon essential oil coated apples and pears: Variability of Aspergillus carbonarius growth and ochratoxin A production. Food Res. Int. 2019, 119, 876-885. [CrossRef]

65. Peretto, G.; Du, W.-X.; Avena-Bustillos, R.J.; Berrios, J.D.J.; Sambo, P.; McHugh, T.H. Optimization of Antimicrobial and Physical Properties of Alginate Coatings Containing Carvacrol and Methyl Cinnamate for Strawberry Application. J. Agric. Food Chem. 2014, 62, 984-990. [CrossRef] 
66. Raybaudi-Massilia, R.M.; Rojas-Graü, M.A.; Mosqueda-Melgar, J.; Martín-Belloso, O. Comparative Study on Essential Oils Incorporated into an Alginate-Based Edible Coating To Assure the Safety and Quality of Fresh-Cut Fuji Apples. J. Food Prot. 2008, 71, 1150-1161. [CrossRef]

67. Guerreiro, A.C.; Gago, C.M.; Faleiro, M.L.; Miguel, M.G.; Antunes, M.D. The effect of alginate-based edible coatings enriched with essential oils constituents on Arbutus unedo L. fresh fruit storage. Postharvest Boil. Technol. 2015, 100, 226-233. [CrossRef]

68. Zhang, Y.; Ma, Q.; Critzer, F.; Davidson, P.M.; Zhong, Q. Effect of alginate coatings with cinnamon bark oil and soybean oil on quality and microbiological safety of cantaloupe. Int. J. Food Microbiol. 2015, 215, 25-30. [CrossRef]

69. Azarakhsh, N.; Osman, A.; Ghazali, H.M.; Tan, C.P.; Adzahan, N.M. Lemongrass essential oil incorporated into alginate-based edible coating for shelf-life extension and quality retention of fresh-cut pineapple. Postharvest Boil. Technol. 2014, 88, 1-7. [CrossRef]

70. Raybaudimassilia, R.; Mosquedamelgar, J.; Martin-Belloso, O. Edible alginate-based coating as carrier of antimicrobials to improve shelf-life and safety of fresh-cut melon. Int. J. Food Microbiol. 2008, 121, 313-327. [CrossRef] [PubMed]

71. Ye, M.; Neetoo, H.; Chen, H. Control of Listeria monocytogenes on ham steaks by antimicrobials incorporated into chitosan-coated plastic films. Food Microbiol. 2008, 25, 260-268. [CrossRef] [PubMed]

72. Mohebi, E.; Marquez, L. Intelligent packaging in meat industry: An overview of existing solutions. J. Food Sci. Technol. 2015, 52, 3947-3964. [CrossRef] [PubMed]

73. Gaikwad, K.; Singh, S.; Ajji, A. Moisture absorbers for food packaging applications. Environ. Chem. Lett. 2019, 17, 609-628. [CrossRef]

74. Toldra, F. Meat Biotechnology; Springer: New York, NY, USA, 2008; pp. 425-452. ISBN 978-0-387-79381-8.

75. Park, Y.W.; Kim, S.M.; Lee, J.Y.; Jang, W. Application of biosensors in smart packaging. Mol. Cell. Toxicol. 2015, 11, 277-285. [CrossRef]

76. Takma, D.K.; Korel, F. Active packaging films as a carrier of black cumin essential oil: Development and effect on quality and shelf-life of chicken breast meat. Food Packag. Shelf Life 2019, 19, 210-217. [CrossRef]

77. Abdallah, M.R.; Mohamed, M.A.; Mohamed, H.; Emara, M.T. Application of alginate and gelatin-based edible coating materials as alternatives to traditional coating for improving the quality of pastirma. Food Sci. Biotechnol. 2018, 27, 1589-1597. [CrossRef]

78. Król, Ż.; Kulig, D.; Marycz, K.; Zimoch-Korzycka, A.; Jarmoluk, A. The Effects of Using Sodium Alginate Hydrosols Treated with Direct Electric Current as Coatings for Sausages. Polymers 2017, 9, 602. [CrossRef]

79. Shahbazi, Y.; Shavisi, N. Effects of sodium alginate coating containing Mentha spicata essential oil and cellulose nanoparticles on extending the shelf life of raw silver carp (Hypophthalmichthys molitrix) fillets. Food Sci. Biotechnol. 2019, 28, 433-440. [CrossRef]

80. Bazargani-Gilani, B. Activating sodium alginate-based edible coating using a dietary supplement for increasing the shelf life of rainbow trout fillet during refrigerated storage. J. Food Saf. 2018, 38, e12395. [CrossRef]

81. Alboofetileh, M.; Rezaei, M.; Hosseini, H.; Abdollahi, M. Efficacy of activated alginate-based nanocomposite films to control Listeria monocytogenes and spoilage flora in rainbow trout slice. J. Food Sci. Technol. 2016, 53, 521-530. [CrossRef] [PubMed]

82. Vital, A.C.P.; Guerrero, A.; Monteschio, J.D.O.; Valero, M.V.; Carvalho, C.B.; Filho, B.A.D.A.; Madrona, G.S.; Prado, I.N.D. Effect of Edible and Active Coating (with Rosemary and Oregano Essential Oils) on Beef Characteristics and Consumer Acceptability. PLoS ONE 2016, 11, e0160535. [CrossRef] [PubMed]

83. Jalali, N.; Ariiai, P.; Fattahi, E. Effect of alginate/carboxyl methyl cellulose composite coating incorporated with clove essential oil on the quality of silver carp fillet and Escherichia coli O157:H7 inhibition during refrigerated storage. J. Food Sci. Technol. 2015, 53, 757-765. [CrossRef] [PubMed]

84. Raeisi, M.; Tabaraei, A.; Hashemi, M.; Behnampour, N. Effect of sodium alginate coating incorporated with nisin, Cinnamomum zeylanicum, and rosemary essential oils on microbial quality of chicken meat and fate of Listeria monocytogenes during refrigeration. Int. J. Food Microbiol. 2016, 238, 139-145. [CrossRef] [PubMed]

85. Oussalah, M.; Caillet, S.; Salmieri, S.; Saucier, L.; Lacroix, M. Antimicrobial effects of alginate-based film containing essential oils of Listeria monocytogenes and Salmonella thyphimurium present in bologna and ham. J. Food Prot. 2007, 70, 901-908. [CrossRef] [PubMed] 
86. Kazemi, S.M.; Rezaei, M. Antimicrobial Effectiveness of Gelatin-Alginate Film Containing Oregano Essential Oil for Fish Preservation. J. Food Saf. 2015, 35, 482-490. [CrossRef]

87. Oussalah, M.; Caillet, S.; Salmiéri, S.; Saucier, L.; Lacroix, M. Antimicrobial Effects of Alginate-Based Film Containing Essential Oils for the Preservation of Whole Beef Muscle. J. Food Prot. 2006, 69, 2364-2369. [CrossRef]

88. Lu, F.; Ding, Y.; Ye, X.; Liu, D. Cinnamon and nisin in alginate-calcium coating maintaing quality of fresh northern snakehead fish fillets. LWT-Food Sci. Technol. 2010, 43, 1331-1335. [CrossRef]

89. Sharifi, F.; Khanzadi, S.; Hashemi, M.; Azizzadeh, M. Control of Listeria Monocytogenes and Escherichia coli O157:H7 Inoculated on Fish Fillets Using Alginate Coating Containing Lactoperoxidase System and Zataria multiflora Boiss Essential Oil. J. Aquat. Food Prod. Technol. 2017, 26, 1014-1021. [CrossRef]

90. Deng, X.; Srinivasan, R. When Do Transparent Packages Increase (or Decrease) Food Consumption? J. Mark. 2013, 77, 104-117. [CrossRef]

91. Silberbauer, A.; Schmid, M. Packaging Concepts for Ready-to-Eat Food: Recent Progress. J. Packag. Technol. Res. 2017, 1, 113-126. [CrossRef]

(C) 2020 by the authors. Licensee MDPI, Basel, Switzerland. This article is an open access article distributed under the terms and conditions of the Creative Commons Attribution (CC BY) license (http://creativecommons.org/licenses/by/4.0/). 